\title{
Fiscal Issues of Old Projects in Real Estate Sales
}

\author{
Wei Sun ${ }^{1}$ \\ ${ }^{1}$ School of Economics and Management, Zaozhuang University, Zaozhuang, Shandong Province, \\ China
}

Keywords: The Change From Business Tax To Value-Added Tax, Real Estate, Old Projects.

\begin{abstract}
As the key industry in the change from business tax to value-added tax, the real estate industry encountered most complex taxation problems in 2016. This paper makes a comprehensive analysis on the special taxation issue of old projects in real estate enterprises in the transition period, and puts forward suggestions on the improvement of relevant policies.
\end{abstract}

\section{Introduction}

On May 1, 2016, the real estate companies began to pay value-added tax instead of business tax. In order to adapt this change, at the end of March 2016, the State Administration of Taxation issued Inerim Management Procedures on Value-added Tax of Real Estate Projects Self-developed and Sold by Real Estate Enterprises, (No. Eighteenth document, 2016. Hereinafter referred to as No. 18 document). The policy makes clear provisions on issues of applicable tax method of real estate projects self-developed and sold by enterprises, deducting land price, tax paid in advance, value added tax calculation, invoicing, tax declaration and other issues. However, in the specific implementation of above provisions, many financial personnel in real estate companies do not grasp, or even misunderstand financial policies, and bring unnecessary losses to their enterprises. Based on comprehensive understanding of No. 18 document, this paper provides in-depth analyses on various situations encountered by old sales projects in real estate business, hoping to help financial personnel to deal with these specific matters.

\section{How to Distinguish Old and New projects}

No. 18 document divides real estate business projects into old projects and new projects. Different tax management policies are implemented in old and new projects. Therefore, the correct distinction of old and new projects is the question of fundamental importance. No. 18 document stipulates, old real estate projects should satisfy one of the following conditions: (1) The Planning Permit of Construction Engineering clearly states, the starting date of project is before April 30, 2016; (2) The Planning Permit of Construction Engineering does not clearly state the starting date of project, or the planning permit has not been obtained yet; but the construction contract marks that the starting date of project is before April 30, 2016.

Above provisions seem clear, but there are a variety of special circumstances which are not included in the policy. For instance, (1) some projects do not have planning permit nor construction contract, but they do start before April 30, 2016; (2) some projects takes phased development method, and have more than two planning permits; the starting dates marked in these permits are respectively before and after April 30, 2016; (3) there's no clear starting date in planning permit; the same project is completed by different companies, while the dates on work contracts are before and after April 30, 2016; (4) the starting date in macro contract of project is before April 30, 2016, but some follow-up projects are not included in the macro contract; there are specified contracts on these follow-up projects, and the dates of these contracts are after April 30, 2016. These situations are often seen in actual work, but the State Administration of Taxation fails to make clear provisions. Local tax departments have different understandings on these circumstances.

The author thinks that: (1) according to the principle of not increasing tax burdens of enterprises, for projects have neither planning permit nor record contract, as long as the enterprises can provide sufficient evidence to prove that these projects started before April 30, 2016, tax methods of old 
projects can be chosen; (2) for phased or continuous development projects, if there are several planning permits or contracts, the earliest date should be adopted as the standard time; (3) real estate enterprises should actively communicate with tax authorities, submit relevant documents and put on records; (4) the State Administration of Taxation need to deal with these problems and make clear indications as soon as possible, in order to unify regulations in local tax authorities.

\section{How to Choose Project Categories}

Document 18 stipulates that, old projects in real estate business can take general way or simple way of taxation. How to choose between these two ways? The author thinks, following analyses and calculations can be made. (1) If the company chooses tax method of old project, value added tax $=$ (total price + other charges) / $(1+5 \%) * 5 \%$; (2) if the company chooses tax method of new project, value added tax $=$ (total price + other charges -- deductible land transferring fees) $/(1+11 \%) * 11 \%$-amount of outsourcing projects* no difference point of the comprehensive income tax rate; (3) make the two equal, (full price + other charges) $/(1+5 \%) * 5 \%=$ (full price + other charges -- deductible land transferring fees) / $(1+11 \%) * 11 \%$-- amount of outsourcing projects* no difference point of the comprehensive income tax rate, the no difference point of the comprehensive income tax rate can be got $=[($ full price + price cost $) * 5.15 \%$-- deductible land transferring fees $* 9.91 \%$ ] the amount of outsourcing projects. After calculating the no difference point of the comprehensive income tax rate, it is possible to select the appropriate taxation method. [1]

For example: the expected sales revenue of a old project is 200 million yuan including tax; land transferring fees is 30 million yuan; other outsourcing projects cost 90 million yuan; no difference point of the comprehensive income tax rate $=(200 * 5.15 \%-30 * 9.91 \% 90=8.14 \%)$. When the actual comprehensive income tax rate is equal to $8.14 \%$, simple tax and general tax methods are the same for the enterprise. (Payable tax in simple method $=200 /(1+5 \%) * 5 \%=9.5238$ million, payable tax in general method $=(200-30) /(1+11 \%) * 11 \%-90 * 8.14 \%=9.5208$; the amounts are basically equal $)$. When the actual comprehensive income tax rate is higher than $8.14 \%$, the general tax method is more favorable for the enterprise. (For instance, assuming the comprehensive income tax rate of a project is $10 \%$, payable tax in simple method $=200 /(1+5 \%) * 5 \%=9.5238$ million, payable tax in general method $=(200-30) /(1+11 \%) * 11 \%-90 * 10 \%=7.8468$. Tax saving is $9.5238-7.8468=1.677$ million yuan). When the actual comprehensive input tax rate is lower than $8.14 \%$, the simple tax method is more favorable for the enterprise. (For instance, assuming the comprehensive income tax rate of a project is $6 \%$, payable tax in simple method $=200 /(1+5 \%) * 5 \%=9.5238$ million, payable tax in simple method $=(200-30) /(1+11 \%) * 11 \%-90 * 6 \%=11.4468$ million yuan. Tax saving is 11.4468-9.5238=1.923 million yuan).

\section{How to Invoice for Advance Payment of Old Projects}

According to relevant value added tax policies, prepaid housing payments are included in liabilities, rather than income. There's no tax obligation. The aim of this treatment procedure is to ensure the timely payment of special taxes. But for the invoicing of prepaid housing payments, the State Administration of Taxation does not make unified regulation, and the understandings of different local tax authorities are different. Most provinces stipulate that, (1) tax authorities do not issue VAT special invoices for prepaid housing payments; but in order to meet the needs of customers, housing provident funds and financial departments, VAT regular invoices can be provided; (2) when issuing invoices, the bar of tax rate should be "zero"; remark column should be marked "prepaid housing payments for real estate enterprises"; (3) after delivering the real estate and confirming income, the regular invoice should be exchanged with VAT special invoice; tax supplement should be made according to applicable tax rate.

The author thinks that, according to China's invoice management procedures, real estate enterprises should confirm the income and then issue the invoice. These provisions issued by local tax departments consider the needs of prepaid taxes and customers, but to a certain extent they violate the invoice management procedures. A more appropriate method goes as following. The State 
Administration of Taxation prints and issues nationwide unified receipt note for prepaid house payment, and coordinates with banks, provident fund management centers and land resources departments, stipulates that the receipt note can be used as invoice in tax processing. After delivering the real estate and confirming income, the receipt note should be exchanged with VAT special invoices or regular invoices. The State Administration of Taxation should make clear provisions on that issue as soon as possible.

\section{How to Pay Tax in the Situation of Buy one and Get One Free in Old Sales Projects}

When selling housing estates, many real estate companies organize promotional activities like free home appliances, furniture and decoration. It is currently controversial for taxation of this business. There are kinds of opinions.

(1) This business is a kind of mixed sale business, which needs to pay VAT at the rate of $11 \%$ or $5 \%$ of house payment. Holders of this view believes that, for free home appliances, furniture and decoration attached with the house, their prices have been included in housing payment. So there is no need pay other VAT. But other free goods which are not included in housing payment, should be regarded as sale goods. Value-added tax should be paid according to tax rate applicable to goods. For example, in promotional activities, a real estate enterprise draws a lottery and gifts home appliances. Customers who do not buy houses of that enterprise can also obtain the gift. The activity shall be regarded as sale of goods, value-added tax should be levied according to the tax rate applicable to goods. [2]

(2)This business is a kind of mixed sale business, which needs to pay VAT at the rate of $11 \%$ or $5 \%$ of house payment. For free home appliances, furniture and decoration attached with the house,VAT should also be paid. Holders of this view believes that, (1) mixed sales refers to sale behaviors involve both services and goods, rather than mixtures of real estate and goods; (2) if the real estate company is a general taxpayer, and get VAT special invoices when purchasing goods, $17 \%$ value added tax can be deducted. If VAT is paid in accordance with principles for mixed sales projects, $11 \%$ VAT should be paid; then the real estate company can pay less $6 \%$ value-added tax, which means the state will suffer the same amount of tax losses. In order to ensure the tax revenue of the state, the above business shall be treated as mixed sale business.

The author believes that, due to the complexity of economic activities, the understanding of tax provisions should not be limited in their literal meaning; the economic essence of provisions should also be considered. The mixed sale treatment of that business can better reflect its essence, and balance the interests of both sides. The State Administration of Taxation needs to make this issue clear as soon as possible, so that local tax departments and real estate enterprises can process related business appropriately.

\section{Accounting for Old Sale Projects}

According to the Provisions for Value-added Tax Accounting Treatment issued by Ministry of Finance (Document of Finance and Accounting, [2016] No.22) and 18th document, accounting treatment for old projects in real estate enterprises goes as follows.

In accordance with the general tax method:

(1) house payment received in advance

debit: bank deposit, credit: deposit received in advance

(2) VAT paid in advance (house payment received in advance / $(1+11 \%) * 3 \%) \quad$ debit: $\quad$ tax payable -VAT paid in advance, credit: bank deposit

(3) after the delivery of building, tax obligation starts, the remaining house payment is received and confirmed

debit: dank deposit, deposit received in advance;

credit: main business income, tax payable - VAT payable (VAT on sales)

(4) For land price which can be deducted from sales volume, debit: tax payable - VAT payable (VAT on sales deducted) 
credit: cost of development

(5)Acquisition of fixed assets and others, value-added tax invoices are obtained debit: fixed assets and others, tax payable - VAT payable (input tax)

credit: bank deposits

(6) the value added tax should be paid at the end of the month, debit: tax payable - VAT payable (transfer out unpaid VAT)

credit: tax payable - unpaid VAT

(7)value-added tax actually paid next month,

debit: tax payable - unpaid value-added tax

credit: bank deposits [3]

For example: in April 2017, a real estate company sales an old property project, and chooses choice the general way of taxation. The total income (include tax) of that project is 200 million yuan; 150 million yuan is received in advance; paid revenues of land selling is 30 million yuan (assuming $60 \%$ can be deducted); all assets purchased costs 40 million yuan (excluding tax price, have special VAT invoices). The relevant accounting treatment goes as follows:

(1) debit: bank deposits 15000, credit: deposit received in advance 15000

(2)VAT paid in advance $15000 /(1+11 \%) * 3 \%=4054.1$ thousand yuan

debit:tax payable - VAT paid in advance 405.41

credit: bank deposit 405.41

(3) debit: bank deposit 5000, deposit received in advance 15000

credit: main business income $20000 /(1+11 \%)=18018.02$, tax payable - VAT payable (VAT on sales) $18018.02 * 11 \%=1981.98$

(4) debit: tax payable- VAT payable (deducted VAT on sales) $3000 * 60 \% /(1+11 \% *$ $11 \%=178.38$ )

credit: cost of development 178.38

(5) debit: fixed assets and others 4000, payable tax - VAT payable (input tax) 680 credits:

bank deposit 4680

(6) debit: tax payable - VAT payable (transfer out unpaid VAT) 718.19

credit: : tax payable - unpaid VAT 718.19

(7) debit: payable tax - unpaid VAT 718.19

credit: bank deposit 718.19

In the form simple tax system:

(1)house payment received in advance, debit: bank deposit, credit: deposit received in advance

(2) VAT paid in advance (house payment received in advance / (1+5\%) *3\%)

debit: tax payable - VAT payable, credit: bank deposit

(3)after the delivery of building, tax obligation starts, the remaining house payment is received and confirmed

debit: dank deposit, deposit received in advance;

credit: main business income, tax payable - simple way of tax

(4) land price cannot be deducted from sales volume,

(5) fixed assets purchased cannot be deducted from input tax,

debit: Fixed assets and others, credit: bank deposits

(6) the value-added tax should be paid at the end of the month,

(7)the actual VAT paid next month, debit: tax payable - unpaid VAT

credit: bank deposits

If the simple way of taxation is chosen, accounting treatment goes as follows,

(1) debit: bank deposits 15000, credit: deposit received 15000

(2) VAT paid in advance $15000 /(1+5 \%) * 3 \%=428.57$

debit: tax payable - VAT paid in advance 428.57 , credit: bank deposit 428.57

(3) debit: bank deposit 5000, depositreceived 15000; 
credit: main business income $20000 /(1+5 \%)=19047.62$, tax payable - simple tax method $19047.62 * 5 \%=952.38$

(4) debit: fixed assets and so on 4680, credit: bank deposits 4680

(5) debit: tax payable - simple tax method 523.81, credit: tax payable - unpaid VAT 523.81

(7) the actual VAT paid next month, debit: tax payable - unpaid VAT 523.81 credit: Bank deposits 523.81

\section{References}

[1] W.T. Duan, Some practical problems of replacing business tax with value-added tax in real estate companies, J. Finance and Accounting. 14 (2016).

[2] Z.M. Zou, VAT related business processing for real estate companies after chancing from business tax to value-added tax, J. Finance and Accounting. 21 (2016).

[3] X.J. Feng, The analysis of the new regulations on the accounting treatment of value added tax in real estate accounting for general taxpayers, J. Finance and Accounting Monthly. 7 (2016). 